\title{
Spiraling Down into Corruption: A Dynamic Analysis of the Social Identity Processes that Cause Corruption in Organizations to Grow
}

Niki A. Den Nieuwenboer and Muel Kaptein

\begin{tabular}{|l|l|}
\hline \multicolumn{2}{|l|}{ ERIM REPORT SERIES RESEARCH IN MANAGEMENT } \\
\hline ERIM Report Series reference number & ERS-2007-086-ORG \\
\hline Publication & December 2007 \\
\hline Number of pages & 30 \\
\hline Persistent paper URL & http://hdl.handle.net/1765/10772 \\
\hline Email address corresponding author & nnieuwenboer@rsm.nl \\
\hline Address & Erasmus Research Institute of Management (ERIM) \\
& RSM Erasmus University / Erasmus School of Economics \\
& Erasmus Universiteit Rotterdam \\
& P.O.Box 1738 \\
& 3000 DR Rotterdam, The Netherlands \\
& Phone: $\quad+31104081182$ \\
& Fax: $\quad+31104089640$ \\
& Email: info@erim.eur.nl \\
& Internet: $\quad$ www.erim.eur.nl \\
\hline
\end{tabular}

Bibliographic data and classifications of all the ERIM reports are also available on the ERIM website: www.erim.eur.nl 


\section{ERASMUS RESEARCH INSTITUTE OF MANAGEMENT}

\section{REPORT SERIES}

\section{RESEARCH IN MANAGEMENT}

\begin{tabular}{|c|c|}
\hline \multicolumn{2}{|c|}{ ABSTRACT AND KEYWORDS } \\
\hline Abstract & $\begin{array}{l}\text { To date, theory and research on corruption in organizations have primarily focused on its static } \\
\text { antecedents. This paper focuses on the spread and growth of corruption in organizations. For } \\
\text { this purpose three downward organizational spirals are formulated: the spiral of divergent norms, } \\
\text { the spiral of pressure, and the spiral of opportunity. Social Identity Theory is used to explain the } \\
\text { mechanisms of each of these spirals. Our dynamic perspective contributes to a greater } \\
\text { understanding of the development of corruption in organizations and opens up promising } \\
\text { avenues for future research. }\end{array}$ \\
\hline Free Keywords & corruption, dynamics, organizational factors, social identity theory \\
\hline Availability & $\begin{array}{l}\text { The ERIM Report Series is distributed through the following platforms: } \\
\text { Academic Repository at Erasmus University (DEAR), DEAR ERIM Series Portal } \\
\text { Social Science Research Network (SSRN), SSRN ERIM Series Webpage } \\
\text { Research Papers in Economics (REPEC), REPEC ERIM Series Webpage }\end{array}$ \\
\hline Classifications & $\begin{array}{l}\text { The electronic versions of the papers in the ERIM report Series contain bibliographic metadata } \\
\text { by the following classification systems: } \\
\text { Library of Congress Classification, (LCC) LCC Webpage } \\
\text { Journal of Economic Literature, (JEL), JEL Webpage } \\
\text { ACM Computing Classification System CCS Webpage } \\
\text { Inspec Classification scheme (ICS), ICS Webpage }\end{array}$ \\
\hline
\end{tabular}


Spiraling Down into Corruption: A Dynamic Analysis of the Social Identity Processes that Cause Corruption in Organizations to Grow

Niki A. Den Nieuwenboer

RSM Erasmus University

Office T07-01

P.O. Box 1738

3000 DR Rotterdam

The Netherlands

Tel. +31 104081899

Fax. +31 104089012

nnieuwenboer@rsm.nl

Muel Kaptein

RSM Erasmus University

Office T07-04

P.O. Box 1738

3000 DR Rotterdam

The Netherlands

Tel. +31 104081923

Fax. +31 104089012

mkaptein@rsm.nl 
Spiraling Down into Corruption: A Dynamic Analysis of the Social Identity Processes that

\title{
Cause Corruption in Organizations to Grow
}

\begin{abstract}
To date, theory and research on corruption in organizations have primarily focused on its static antecedents. This paper focuses on the spread and growth of corruption in organizations. For this purpose three downward organizational spirals are formulated: the spiral of divergent norms, the spiral of pressure, and the spiral of opportunity. Social Identity Theory is used to explain the mechanisms of each of these spirals. Our dynamic perspective contributes to a greater understanding of the development of corruption in organizations and opens up promising avenues for future research.
\end{abstract}

Key words: Corruption, Dynamics, Organizational Factors, Social Identity Theory 


\section{Spiraling Down into Corruption: A Dynamic Analysis of the Social Identity Processes that}

\section{Cause Corruption in Organizations to Grow}

Comer once said "Fraud is contagious and corrosive; allow small frauds to escape unpunished and they will soon grow” (1985: 6). In the popular press too, fraud and other types of corruption are frequently referred to as “a virus” (USA Today, 2005) and “a cancer” (SmartPros, 2002). The fact of the matter is, however, that academic research on the subject generally finds low base-rates for corruption in organizations (Aquino, Lewis and Bradfield, 1999; Colbert, Mount, Harter, Witt and Barrick, 2004; Duffy, Ganster and Pagon, 2002). Yet it just is not logical that the major corruption cases that have hit the business community (Enron, WorldCom, Arthur Andersen, etc.) became what they have become out of nothing. Some sort of process must have taken place in these companies through which they turned increasingly corrupt over time. How can such an apparent self-sustaining growth of corruption be explained?

Much theoretical and empirical research has been conducted into the causes of corruption in organizations (e.g. Baucus and Near, 1991; Daboub, Rasheed, Priem and Gray, 1995; Treviño and Weaver, 2003; Vardi and Weitz, 2004). Most of these studies focus on individual, organizational, and/or environmental factors and examine the relationship of each factor to corruption independently. Weick (1979), however, holds that when factors are highly interdependent - as many organizational processes are (Masuch, 1985) - focusing on a single factor obscures the fact that organizational degradation processes may grow in scale over time. Although Robinson and Greenberg made a case for examining the dynamics of corruption in organizations in 1998, Treviño, Weaver and Reynolds (2006) have had to repeat that call as few studies thus far touched on this apparent dynamic nature of corruption. Notable exceptions are Ashforth and Anand (2003) Brass et al. (1998), Brief et al. (2001), and Fleming and Zyglidopoulos (2008).

This paper takes up the challenge of creating a greater understanding of how corruption grows and develops over time. We begin by defining the concept of the "organizational dynamics of corruption.” We then introduce three organizational factors we deem relevant to the occurrence of 
corruption in the workplace. These factors are derived from Cressey's (1953) theory of trust violations. As Giddens (1984) pointed out, the social context of individuals both enables and inhibits any type of - behavior. In the current paper it is therefore argued that social structures inhibit, enable and stimulate people to commit corruption, and may even force people into corruption. Connecting both ideas, we here advance a theory of downward corruption spirals. Social Identity Theory (Tajfel and Turner, 1979) is used to describe how such dynamic downward spirals may come into being inside three organizational factors. Downward spirals are defined as self-sustaining deterioration processes of one or more organizational factors that increasingly intensify the scale of corruption.

\section{The Organizational Dynamics of Corruption Defined}

Following Sherman (1980), Ashforth and Anand define corruption as "the misuse of authority for personal, subunit and/or organizational gain” (2003: 2). They interpret misuse of authority as violating organizational and/or societal norms by way of using whatever one is entrusted with in the course of performing ones job. Corruption can be caused by individual characteristics (e.g. Treviño and Youngblood, 1990) and environmental factors (e.g. Baucus and Near, 1991). The focus of this paper is on organizational factors. As organizational factors are embedded in the structure and culture of the organization and as such may stimulate (e.g., Treviño, Butterfield and McCabe, 1998) or impede (e.g., Tyler and Blader, 2005) employee corruption, they form the points of departure for developing organizational policies and measures against corruption (Hoffman and Moore, 1990; Paine, 2003; Pastin, 1986; Treviño and Weaver, 2003). The presence of these factors does not imply that corruption indeed occurs; it merely indicates the likelihood of corruption taking place. Conversely, corruption does not necessarily mean that organizational factors have caused it, as it may also be a product of environmental or individual factors alone.

The relationship between organizational factors and corruption is usually depicted as a static

relationship. For example, Peterson (2002a) focuses on the impact of the ethical climate, Zey-Ferrell and Ferrell (1982) on the impact of role-set configurations and opportunities, and Vardi and Weitz 
(2004) on the impact of job autonomy on corruption. Some studies focus on a single factor, such as Sims and Brinkmann (2002) who focus on the impact of leadership, while others take a number of factors and levels into account (e.g., Brief, Dukerich, Brown and Brett, 1996; Giacalone and Greenberg, 1997; Treviño and Weaver, 2003). In addition to such types of static relationships more complex and dynamic relationships can also be found. In dynamic relationships "a closed loop” exists (Senge, 1990; Sterman, 2000). In that case a change of a factor sets in motion another change within that factor. In the event of a negative relationship between the changes, the change is counteracted, whereby a new equilibrium might be established (Masuch, 1985). A spiral develops when there is a self-sustaining process of one directional change within the factor as it continuously reacts to changes that occur within itself (cf. Andersson and Pearson, 1999; Lindsley, Brass and Thomas, 1995). In a downward corruption spiral, the changes that occur are "deviation amplifying” (Masuch, 1985; Weick, 1979), consequently increasing the likelihood of corruption. ${ }^{1}$

\section{Theoretical Foundations}

\section{Cressey's Theory of Trust Violations}

Donald Cressey, a prominent academic in the area of organized crime (Hobbs, 1997), studied the circumstances that lead employees to commit crimes in organizations. He developed a theory of trust violations (Cressey, 1950) which was supported by a qualitative study for which he interviewed 300 incarcerated embezzlers (Cressey, 1953, 1965). In his work, Cressey argued that there are three factors which all have to be present for "trust violators" to commit violations. These are rationalization, pressure, and opportunity. Rationalization refers to the vocabularies of adjustment that violators use to legitimize their behavior. Pressure refers to a perceived non-sharable problem which acts as a motivator to commit a violation. The factor of opportunity refers to violators having the means at their disposal to commit their violation. More importantly it refers to violators' perceptions about the risks of getting caught. The underlying motivation to embezzle according to Cressey was related to status maintenance or status enhancement. Although many scholars in the organizational sciences cite Cres- 
sey’s work (e.g., Ashforth and Anand, 2003; Gottfredson and Hirschi, 1990; Hallier and Forbes, 2004; Vardi and Weitz, 2004), and although it also receives much attention in more popular work (e.g., Albrecht et al., 1984; Comer, 1985; Davies, 2000; Wells, 2004), his theory has hardly been developed further. In this paper Cressey’s theory is developed further in that downward organizational spirals are identified within the three factors that he proposed. These, to our opinion, can cause organizational corruption to grow.

Cressey's theory is suited to our objective of developing a theory of the dynamics of corruption for four reasons. Firstly, Cressey’s theory as well as ours focuses on explaining human behavior in organizations. Secondly, Cressey purposely omitted employees that took their job for the reason of stealing (career criminals; Gottfredson and Hirschi, 1990). Rather, Cressey's theory, as does our theory, focuses on identifying the circumstances in which "ordinary men do extraordinary things" (Braithwaite, 1984: 2). Thirdly, Cressey's theory is suited to our purposes as the circumstances or factors he lists are relevant for all types of corruption. Although the population in his empirical study mainly consisted of embezzlers Cressey’s theory aims at explaining all types of trust-violations. Hence, the object his study, the violation of legitimate organizational or societal norms and thus the abusing of organizational or societal trust corresponds with our object of study. Fourthly, we use Cressey's theory because of its simplicity; if the factors increase then so does the risk that violations will occur.

\section{Social Identity Theory}

We use Social Identity Theory (SIT) to describe how downward spirals can form in the three factors discussed above. We believe that this theory is appropriate to use because, firstly, SIT is a dynamic theory (see, for example, Brown and Ross, 1982; Reed and Aquino, 2003; Reicher, Haslam and Hopkins, 2005). This is in keeping with our purpose of explaining the organizational dynamics of corruption. Secondly, numerous studies have already related either people's identities as such to corruption (e.g. Mistangyi, Weaver and Elms, 2008) or concepts central to SIT to corruption. These include concepts such as depersonalization (e.g., Ashforth and Anand, 2003; Brief et al., 2001) and status and 
self-esteem like Cressey (1953) himself, but also Buckley, Wiese and Harvey (1998) and Raelin (1994). We thirdly prefer SIT over other status-literature such as that of Goffman (e.g., 1959) and Ridgeway (1991) because of the group-dynamic perspective that we feel is pivotal to the growth of corruption. This is much more pronounced in SIT than other status literatures.

SIT has its origins in Festinger's (1954) theory of social comparisons, which was transformed by Tajfel (1978) and Tajfel and Turner (1979) into a theory of social identity. Although the focus was initially on intergroup relations, the theory has, more recently, also been applied to interpersonal relations (Hogg, 2000). More detailed discussions of SIT can be found in Ashforth and Mael (1989), Hogg and Tindale (2003), or Tajfel (1982). Here, a brief discussion of the central tenets of the theory suffices. The theory will be discussed further in the sections on the different spirals.

A central feature of SIT is that people classify themselves and others into different social groups. These groups provide information to their members about who they are in social terms. This helps group members to define whether they are similar to or different from individuals in outgroups, and whether they are of higher status than members of out-groups. Group members derive their self-esteem from the status of the group they belong to compared to that of other groups. In the interpersonal applications of SIT, individuals determine their status on the basis of the treatment they receive from other in-group members, and on the basis of their position within the in-group (Hogg, 2000). Self-esteem is seen both as an important motivator and outcome of interpersonal and intergroup behavior, and it functions in a similar manner in situations where self-evaluative judgments are derived from both interpersonal and intergroup comparisons (Hogg, 2003). In addition to resulting in perceived differences in status between the in-group and out-group, comparisons between in-group and out-group result in the entire structure of intergroup and interpersonal behaviors. This is also the case in the inter-personal application of SIT where the self is the "in-grouper" and the other the "outgrouper.”

Another central notion of SIT is depersonalization and adoption of the group’s prototype. According to SIT (Hogg, 2000), people have a desire to know and to adopt what is prototypical of the group both in terms of behavior as in terms of norms. In adopting the group’s prototype, and there- 
fore behaving prototypically and adopting prototypical norms of the group, group members become depersonalized and negate their own personal identity. Lastly, it is important to note that members' shared cognition lies at the very heart of processes related to social identity (Tindale, Meisenhelder, Dykema-Engblade and Hogg, 2003).

\section{Cressey's Theory and Social Identity Theory on Organizational Level}

In this paper, the three factors identified by Cressey are considered on the level of the organization, where the organization is defined in SIT-terms, namely as a group. A group is a collection of individuals that perceive themselves as members of the same group (Tajfel and Turner, 1979). It is important to note that a group can constitute an entire organization, but can also constitute only a subunit of an organization such as a local office, department or working team. It can even comprise people holding the same positions within an organization that do not work together. What exactly "the in-group” is, hence, depends on what group members perceive and define it to be.

Cressey did not explicitly define the relevant levels of analysis of the factors he discerned. Seeing our ambition to find organizational spirals that explain the growth of corruption, we focus on the organizational aspects of the factors he discerned. The exact focus we take on Cressey's three factors is addressed in the following section on the downward corruption spirals.

\section{Downward Corruption Spirals}

In this section we discuss the downward spirals of corruption. The three spirals are depicted in Figure 1 and summarized in Table 1.

FIGURE 1 ABOUT HERE 
TABLE 1 ABOUT HERE

\section{Spiral of Divergent Norms}

Research on corruption has shown that groups can develop norms that are far removed from generally accepted societal norms. Such groups and organizations include Nazi doctors during World War II (Goldhagen, 1996), gangs (Cloward and Ohlin, 1969), the company Salomon Brothers during the 1980s (Darley, 2001), Arthur Andersen (Toffler and Reingold, 2003), and Enron (Sims and Brinkmann, 2003). Sherman (1985) also found groups of police officers who gradually and collectively turned from good cops into corrupt cops. Moore et al. (2006) provide examples of how minor questionable conduct of auditors can escalate into substantial violations through an unnoticed deterioration of group norms.

Cressey (1953) uses the label of rationalization to explain this deviation from social norms. What Cressey found was that violators explain their deviant behavior by using language that enables them to look at it as non-criminal, as justified, or as something for which they themselves are not to blame. Both Ashforth and Anand (2003) and Brief et al. (2001) include rationalizations in their theories on the development of corruption. They argue that people who commit corruption negate the illegitimacy of their acts through rationalizations. However, these scholars, like Cressey, refer to situations in which corruption is already widespread. We, however, focus on the process how this comes to be that way. Hence we concentrate on the process of a group's norms departing from outside norms, the result of which are rationalizations. We therefore relabel this process as the spiral of divergent norms. This spiral describes how groups come to be in such an isolated position that their members lose touch with generally accepted outside norms. Through this process the collective norms and behavior deteriorate over time whilst group members fail to recognize that. As a consequence, corruption may grow. 
Our spiral of divergent norms is fueled by the phenomenon of positive distinctiveness of the in-group (Darley, 2003; Turner and Brown, 1978; Van Knippenberg, 1978). According to Tajfel and Turner (1979), groups differentiate themselves from other groups because of a desire for positive distinctiveness of the in-group. By doing so groups maintain superiority over relevant out-groups and foster a positive social identity. Tajfel and Turner argue that the pursuit of positive distinctiveness is competitive, and creates intergroup conflicts. The result of these conflicts is, as Cloward and Ohlin (1969) found, that the group closes ranks. Conflicts also increase a group’s cohesiveness and the group members' commitment (Staw, Sandelands and Dutton, 1981). The group’s focus turns inward and, more importantly, it detaches from its surroundings. The need for positive distinctiveness of the in-group on the one hand causes a group to rationalize and change its norms. This is further increased by group members' tendency to exaggerate their alienation from outside norms (Cohen, 1955). On the other hand it ensures that the norms, rules or habits that develop within the in-group continue to be considered as legitimate and positive, even when the group's members in fact engage in corruption. The nature of the need for positive distinctiveness ensures, should the group receive negative feedback from out-groups on their norms or corrupt behavior, that the group changes its norms and closes ranks even more.

The in-group's detachment from its surroundings and increased conflict with the outside world intensifies the divergence between the norms of the in-group and generally accepted outside norms. According to Armstrong, Williams and Barrett (2004), this increases the risk of the development of phenomena such as escalating commitment and risky shift, both of which they believe led to the moral decline of organizations such as Enron and WorldCom. Although in psychological literature the phenomenon of risky shift has been developed further into the well-established phenomenon of group polarization (Brauer, Judd and Gliner, 1995), the relevance and importance of the shift toward an extreme, associated with group polarization, is relevant and contributes to a group’s detachment from its surroundings. Such detachment also causes an organization to cease to take notice of the consequences of the behavior of its members (Bovens, 1998) which further widens the gap between in-group and out-group norms. 


\section{Spiral of Pressures}

The spiral of pressures explains why a self-perpetuating increase in organizational pressures could lead to an equally perpetuating increase in corruption. Studies found that performance pressure, for example in the form of performance targets (see, for example, Hollinger and Clark, 1983; Schweitzer, Ordóñez and Douma, 2004; Treviño, 1986), is related to corruption. The gist of this spiral is that one is likely to commit the kind of corruption that increases one's status, and that high pressures on performance thus seduce people to engage in any type of corruption that increases one's performance. And when one starts to commit performance-driven corruption, one gets trapped in it, experiencing an increasing pressure to commit more and more corruption. This effect may be intensified when other colleagues already perform well through corrupt means.

Both Ridgeway (1991) and Goffman (1974) make the point that status is usually determined by issues that are salient. Hence, in a context in which performance is salient, it is one's performance that determines one's status. We therefore argue that in contexts in which performance is salient, people are prone to commit any type of corruption that improves their performance. The regulating mechanism associated with this spiral is related to status and identity threats. As discussed earlier, one of the central tenets of SIT is that groups provide people with a sense of social status from which they derive self-esteem (Tajfel and Turner, 1979). Things that threaten one’s social identity, threats to one's status being among those, should therefore be counteracted. In their discussion of "social creativity,” Tajfel and Turner hint at the possibility of corruption being a response to identity threats (1979: 43). Scholars have, however, only recently begun to explore the relationship between threats to social identity and behavioral responses to such threats. Aquino and Douglas (2003) for example, found in a survey among 308 employees that people in such cases indeed resort to corruption.

When performance targets are reached through corruption, and this does not get punished, status increases on the basis of one's success in reaching those targets. What equally increases, though, is the threat of losing this higher status. Hence performing well through corruption will automatically increase the threat to identity, starting a self-perpetuating spiral of increasing pressures 
to commit corruption. We expect that this effect is more pronounced in people with higher selfesteems than those with lower self-esteems. Baumeister, Smart and Boden (1996) namely found that threats of damage to a high self-esteem evoked a stronger and more erratic behavioral response than attempts to improve low self-esteem. This finding supports our argument that the greater the identity threat, the more likely one will refer to corruption - as one can argue that corruption can be a drastic or irrational response. Baucus and Near’s (1991) finding that successful organizations are more prone than unsuccessful organizations to develop corruption within their ranks also supports this argument.

The mechanism applies to the self as "in-grouper" as well as a group or organization as "ingroup.” The effect turns into a self-perpetuating spiral because in order to protect the in-group’s image the corruption it commits needs to be covered up. This generates more deceit (Cabral-Cardoso, 2004). Equally problematic is the subsequent prolonging of the in-group's success. Success is perverted because if one wants to continue to be successful, one has to continuously improve one's performance to stay ahead in the "battle of competition” (Peterson, 2001: 29). It is comparable to addictions, a comparison also drawn in The Financial Times (2006). Addictions tend to escalate over time (Leonard, 1989). Past success creates higher expectations, and meeting the expectations created by success achieved through corruption is likely to be difficult if not impossible without reverting to (more) corruption. As long as the in-group does not give up the desire to be successful and accept a loss of face, status, and damage to their self-esteem, corruption is likely to only grow.

As said before, this spiraling effect is amplified when others in an in-group's surroundings already meet their targets through corruption. This could in fact also force those that are unwilling to commit corruption into committing it nonetheless. People will generally not want to fall behind their peers in their performance - especially not in extremely competitive environments, or in cases where perpetrators do not get punished or even get rewarded for their corrupt performance. Organizations also often do not wish to fall behind their competitors. If out-groups reach their targets through corruption, sooner or later in-groups will start feeling compelled to engage in corruption. And as the numbers involved in corruption increase, everyone committing it will feel compelled to continue and commit it on an even wider scale. This second mechanism is corroborated by the findings of Robin- 
son and O’Leary-Kelley's (1998) cross-level field study among 187 employees from 35 groups in 20 organizations that showed that the level of corruption exhibited by an individual was positively related to the level of corruption exhibited by their co-workers.

\section{Spiral of Opportunity}

The last spiral we explore is the spiral of opportunity. The importance of the organizational factor of opportunity in the occurrence of corruption has been noted by many scholars (e.g., Baucus, 1994; Tyler and Blader, 2000; Vaughan, 1983). The main feature of the factor of opportunity is that the risk of getting caught and/or punished is such that it does not deter (potential) perpetrators. This spiral is driven by a change in the prototype of the group. The behavior of the manager is essential in this, as a large part of what is considered prototypical is determined by a manager's behavior and because (s)he is primarily responsible for detecting and punishing offenders. Not just a manager's punishing behavior is important; his or her own rule abiding or disobeying behavior is important too. The gist of the spiral of opportunity is that once a manager falls short in correcting corruption or demonstrates corrupt behavior him or herself, that this changes the prototype. And once this prototype change sets in, it becomes increasingly difficult to correct corrupt behavior of employees. Corruption will thus become more and more accepted and spread in the part of the organization that the manager is responsible for. This can even occur despite the manager "officially" endorsing norms that define corruption as unacceptable. As this process continues, the opportunity to commit corruption increases continuously.

According to Turner (1982), individuals base their assessment of prototypical behavior of the in-group mainly on the people who provide the most critical information about behavior and norms. Many authors hold that managers fulfill this function (e.g., Alvesson and Willmott, 2002; Stead et al., 1990; Treviño, Brown and Hartman, 2003). Management, therefore, greatly influences what is considered prototypical. In today’s business, values-based management - rather than compliance-based management - is increasingly popular. Several scholars (e.g., Paine, 1994; Peterson, 2002b; Treviño, Weaver, Gibson and Toffler, 1999) have found that values-based management styles are more effec- 
tive and create better cultures. Leaders that are highly prototypical are more efficient at such management styles as "they and their suggestions are intrinsically persuasive because they embody the norms of a group” (Hogg, 2003: 70). These management styles are quite identity focused. Norms are embodied in a prototype that people want to be, rather than just follow, as people are intrinsically motivated to adopt that what is considered prototypical (Hogg, 2000). Tyler and Blader (2005) found evidence that confirms the effectiveness of such identity-based mechanism in preventing people from breaking rules.

This spiral starts when leaders refrain from imposing sanctions on someone engaging in corruption. By letting instances of corruption slide, it becomes more prototypical. As that prototypicality also reflects on how the leader is perceived, it becomes increasingly difficult for this leader to punish behavior associated with it. The more corruption has been tolerated and is prototypical, the greater the difficulty to punish it. As problems with punishing corruption increase the opportunities to engage in it grow, further complicating punishment. We are not aware of any empirical studies that (indirectly) tested this mechanism. Some scholars, however, have suggested that condoning unethical behavior makes it increasingly difficult to punish and that inconsistent behavior (e.g., first condoning and then punishing corruption) is met with resistance (see, for example, Jackall, 1988; Staw, 1981; Treviño, Hartman and Brown, 2000). Also managers who do not consistently follow through with (ethics) policies run a greater risk that their subordinates will engage in corruption (Hegarty and Sims, 1978; Sims and Brinkmann, 2002; Kaptein, 2005). These studies support our point that when managers let corruption slip, the difficulty to punish it increases. The importance of identity based models rather than interactional justice or leader legitimacy in this matter is supported by Tyler and Blader’s work (2000, 2005).

As corruption is, per definition, rewarding for those committing it, this behavior is likely to self-perpetuate if not deterred. Corruption is therefore likelier to become part of the prototype, given the room, than behavior that does not result in gains. This process turns into a spiral very easily as at the moment that certain behavior is exhibited, the prototype changes and the behavior becomes part 
of the prototype. This spiral will thus lead to a spread of corruption, as all behavior that is part of a prototype is likely to be adopted by all organizational members.

\section{Direction for Future Research and Management Practice}

Existing theories of corruption predominantly focus on static antecedents of corruption in organizations. In this paper, we developed a theory of dynamic organizational factors, which aims to provide a more comprehensive understanding of corruption. Dynamic processes, as conceptualized by Masuch (1985), were introduced into three organizational factors, which were derived from Cressey's (1953) theory of trust violation. The mechanisms underlying the downward spirals we identified were explored using Social Identity Theory. The social identity approach used in this paper could help management scholars find a motivational theory for how corruption grows and why it is so insidious and contagious. In this final section we discuss the implications for future research and management practice.

\section{Future Research}

The theory discussed in this paper opens up promising avenues for future research. A first important area of future research involves the expansion of our dynamic theory of organizational factors by integrating factors on the individual level (see, for example, Ashton, 1998; Kohlberg, 1981; Treviño and Youngblood, 1990) and factors on the environmental level (see, for example, Baucus and Near, 1991; Daboub et al., 1995; Staw and Szwajkowski, 1975) into the organizational dynamics of corruption. The question is whether downward spirals also exist at these levels, and, if they do, what their relation is to organizational spirals. Organizational opportunities may interact with individual factors as the opportunity to engage in corruption not only tests the individual integrity of employees, but illinclined employees also actively create organizational opportunities (Coleman, 1987). An example of the interaction between organizational and environmental factors is given by Clinard and Yeager 
(1980). They argue that the more market power an organization has, the easier it is to engage in corruption, and vice versa.

A second research question is whether or not other relevant organizational factors can also develop spirals. The three factors in our theory were derived from Cressey's (1953) theory and although Cressey holds that these three factors are necessary and sufficient, we do not rule out the existence of other organizational factors. To fully explain corruption in organizations in terms of organizational spirals, a more thorough review and analysis of other organizational factors, such as perhaps the eight factors listed by Vardi and Weitz (2004), is required. However, factors such as role modeling of managers (Hollinger and Clark, 1983; Sims and Brinkmann, 2002; Treviño et al., 2003), organizational openness (Bird, 1996; Bovens, 1998; Punch, 1996), and organizational justice (Adams, 1965; Greenberg and Cropanzano, 2001; Treviño and Weaver, 2001) can also be reinterpreted as included in our operationalization of Cressey's model. The same holds for SIT. Although SIT explains our spirals well, other theories may help to further understand the complexities and dynamics of corruption in organizations. Social learning theories (Sutherland, 1983) and social network theories (Brass et al., 1998) have both also been related to corruption.

A third interesting area of research concerns the question of whether upward corruption spirals exist and how they are related to downward spirals. Were SIT also to help understand such upward spirals, the central question would be what determines whether an upward or a downward spiral starts and when equilibriums are established. Furthermore, this paper does not suggest the inevitability of ever-growing corruption: that once started, there is an inexorable slide into the abyss. The promising research question therefore is what mechanisms inhibit and stop the generation of spirals.

A fourth challenging area of research concerns exploring the dynamical relationships between the three organizational factors used in this paper. We focused on the dynamics within organizational factors but the spirals likely also interact with each other. For example, Darley (2001) discusses corrupt practices at group level in a study of Prudential-Bache and Salomon Brothers. In these firms, high targets put employees under enormous pressure to perform. This led employees in both organizations to ignore their employers’ noble sounding ethical principles and codes of conduct. They had 
to ignore them in order to protect their identities and maintain their individual and collective success, with the result that organizational norms diverged further. Through this mechanism, the realization of performance targets gained in importance, whereby the pressure to reach them increased, which further stimulated the degeneration of organizational norms. The spiral of divergent norms and the spiral of pressures seem to have interacted here. The spirals of opportunity and divergent norms may interact also. According to Beets and Kilough (1990) the function of an organization’s sanctioning system is to reinforce desirable norms. When an organization's sanctioning system fails, employees will perceive the proclaimed desirable norms as window-dressing, which creates room for the development of other, perhaps less desirable and more deviant norms. When desirable norms lack legitimacy this diminishes the sanctioning capacity of an organization, as under such circumstances employees cannot reasonably be held accountable for their actions (Bovens, 1998). Brief et al. (2001) indicate the presence of interaction between the factors of organizational pressures and opportunity. They suggest that a combination of high performance goals and severe punishment when they are not met, or lavish rewards when they are met, forces others to engage in corruption either to avoid losing face or to secure their status in the group.

A fifth interesting research question relates to the extent to which our dynamic use of SIT also applies to the spread of positive (yet perhaps still deviant) norms in organizations, such as in the case of innovativeness (cf. Burt, 1987).

\section{Testing the Theory}

The most crucial research questions related to our theory of the development of corruption concern whether, and to what extent, these spirals actually exist in practice, to what degree they are selfsustaining, and whether SIT also explains them well in empirical settings. The subject of our theory makes it difficult to depend on common methodologies such as questionnaires or (participant) observation, partly because studying the development of corruption will generally only be possible after it has been uncovered. This has many implications for the objectivity of the data that is gathered. A time-study approach (see for example Druskat and Wheeler, 2003) might be most appropriate, as it 
allows for a reconstruction of the development of corruption and the organizational factors over time. It would be useful to include people in the study who were part of the same group or unit as the ones committing corruption, but were not implicated themselves. The structured interview is a methodology that could be useful despite that the risk of bias might be greater than with other methodologies (Liedtka, 1992, Treviño and Weaver, 2003).

Trust games are a second methodology that can be useful for our purposes. These experiments have been related to the evolvement of trust and cooperativeness (Macy and Skvoretz, 1998), positive reciprocity (McCabe et al., 2003), and group affiliation and independence (refusing to become party to clients' fraudulent schemes) of external auditors (King, 2002). These phenomena are closely related to the underlying mechanisms of the spirals we discerned. In carefully chosen settings, such experiments should enable us to at least examine changes in people's norms, changes in people's cooperativeness with in-group when its successfulness changes, or their willingness to adopt dubious norms and behaviors. Questionnaires administered after the experiment can be used to analyze the motivations behind people’s actions during the experiment. In this way, the value of SIT can be examined. Computer simulations, such as those performed by Macy and Skvoretz (1998), can be helpful in examining the diffusion of behavior and norms hence expanding the group of people involved.

\section{Management Implications}

The Sarbanes-Oxley Act and the increased media attention to corporate corruption in recent years have made corruption detection and prevention a management priority. Corruption is a complex phenomenon because it is multi-faceted. It manifests itself in different behaviors, it may have many different dimensions on which it increases in scale and it has several interconnected causes on multiple levels. Organizations may not even notice that corruption is developing inside its ranks. The perversity of corruption lies in the fact that it can actually have a positive impact on an organization's performance, something Swartz and Watkins (2003) suggested happened at Enron. The increased focus on the in-group may increase employees' willingness to work harder, lead them to call in sick less, 
and enhance their commitment to the organization (Davies, 2000; Punch, 1996). Given the selfreinforcing character of organizational factors, organizations should learn to read early warning signs not only of corruption but also of its - changing and interrelated - antecedents to avoid getting caught in downward spirals. This paper proposes that management take employees' identity perceptions and also their perceptions of the organizational factors into account when designing measures to prevent corruption. These factors can, for example, be assessed periodically by asking employees to fill out a questionnaire regarding the organizational norms they experience, the pressures they feel and the scope they see for misbehaving (cf. Kaptein and Avelino, 2005). Preventing corruption in the workplace, on the whole, requires an understanding of the dynamic complexities of its organizational antecedents. We hope that our dynamic model of corruption spirals assists managers in gaining a better understanding of the causes of corruption and the reasons why it spreads like a virus. 


\section{References}

Abrams, D. and M. A. Hogg: 2003, 'Collective Identity: Group Membership and self-conception’ in Blackwell Handbook of Social Psychology: Group Processes. M.A. Hogg and S. Tindale (eds.) (Malden: Blackwell Publishing).

Adams, J. S.: 1965, 'Inequity in Social Exchange' in Advances in Experimental social psychology, 2.

L. Berkowitz (ed.) (New York: Academic Press).

Akkermans, H. and K.van Helden: 2002, 'Vicious and Virtuous Cycles in ERP Implementation: A Case of Interrelations between Critical Success Factors', European Journal of Information Systems 11, 35-46.

Albrecht, W. S., K. R. Howe and M. B. Romney: 1984, Deterring Fraud: The Internal Auditor's Perspective (Altomonte Springs: The Institute of Internal Auditor's Research Foundation).

Alvesson, M. and H. Willmott: 2002, 'Identity Regulation as Organizational Control: Producing the Appropriate Individual’. Journal of Management Studies 39, 619-644.

Andersson, L. M. and C. M. Pearson: 1999, 'Tit for Tat? The Spiraling Effect of Incivility in the Workplace', Academy of Management Review 24, 452-471.

Aquino, K. and S. Douglas: 2003, 'Identity Threat and Antisocial Behavior in Organizations: The Moderating Effects of Individual Differences, Aggressive Modeling, and Hierarchical Status’, Organizational Behavior and Human Decision Processes 90, 195-208.

Aquino, K., M. U. Lewis and M. Bradfield: 1999, 'Justice Constructs, Negative Affectivity, and Employee Deviance: A Proposed Model and Empirical Test’, Journal of Organizational Behavior 20, 1073-1091.

Armstrong, R. W., R.J. Williams and J. D. Barrett: 2004, 'The Impact of Banality, Risky Shift, and Escalating Commitment on Ethical Decision Making', Journal of Business Ethics 53, 365370.

Ashforth, B.: 1994, 'Petty Tyranny in Organizations', Human Relations 47, 755-778.

Ashforth, B. E. and V. Anand: 2003, 'The Normalization of Corruption in Organizations', Research in Organizational Behavior 25, 1-52.

Ashforth, B. E. and F. Mael: 1989, 'Social Identity Theory and the Organization', Academy of Management Review 14, 20-39.

Ashton, M. C.: 1998, 'Personality and Job Performance: The Importance of Narrow Traits', Journal of Organizational Behavior 19, 289-303.

Baucus, M. S.: 1994, 'Pressure, Opportunity and Predisposition: A Multivariate Model of Corporate Illegality’, Journal of Management 20, 699-721.

Baucus, M. S. and J. P. Near: 1991, ‘Can Illegal Corporate Behavior Be Predicted? An Event History Analysis', Academy of Management Journal 34, 9-36. 
Baumeister, R. F., L. Smart and J. M. Boden: 1996, 'Relation of Threatened Egotism to Violence and Aggression: The Dark Side of High Self-esteem', Psychological Review 103, 5-33.

Beets, S. D. and L. N. Killough: 1990, 'The Effectiveness of a Compliant-based Ethics Enforcement System: Evidence of the Accounting Profession', Journal of Business Ethics 9, 115-127.

Bird, F. B.: 1996, The Muted Conscience: Moral Silence and the Practice of Ethics in Business (Westport: Quorum Books).

Bovens, M.: 1998, The Quest for Responsibility: Accountability and Citizenship in Complex Organizations (Cambridge: Cambridge University Press).

Braithwaite, J.: 1984, Corporate Crime in the Pharmaceutical Industry (London: Routledge \& Kegan).

Brass, D. J., K. D. Butterfield and B. C. Skaggs: 1998, 'Relationships and Unethical Behavior: A Social Network Perspective', Academy of Management Review 23, 14-31.

Brauer, M., C. D. Judd and M. D. Gliner: 1995, 'The Effects of Repeated Expressions on Attitude Polarization during Group Discussions', Journal of Personality and Social Psychology 68, 1014-1029.

Brief, A. P., R. T. Buttram and J. M. Dukerich: 2001, 'Collective Corruption in the Corporate World: Toward a Process Model' in Groups at Work: Theory and Research. M. E. Turner (ed.) (Mahwah: Lawrence Erlbaum Associates Publishers).

Brief, A. P., J. M. Dukerich, P. R. Brown and J. F. Brett: 1996, 'What's Wrong with the Treadway Commission Report? Experimental Analyses of the Effects of Personal Values and Codes of Conduct on Fraudulent Financial Reporting', Journal of Business Ethics 15, 183-198.

Brown, R. J. and G. F. Ross: 1982, 'The Battle for Acceptance: An Investigation into the Dynamics of Intergroup Behavior' in Social Identity and Intergroup Relations. H. Tajfel (eds.) (Cambridge: Cambridge University Press).

Buckley, M. R., D. S. Wiese and M. G. Harvey: 1998, 'An Investigation into the Dimensions of Unethical Behavior', Journal of Education for Business 73, 284-290.

Burt, R. S.: 1987, 'Social Contagion and Innovation: Cohesion versus Structural Equivalence', The American Journal of Sociology 92, 1287-1335.

Cabral-Cardoso, C.: 2004, 'Ethical Misconduct in the Business School: A Case of Plagiarism that Turned Bitter', Journal of Business Ethics 49, 75-89.

Clinard, M. B. and Yeager, P. C.: 1980, Corporate Crime (New York: Free Press).

Cloward, R. A. and L. E. Ohlin: 1969, 'The Evolution of Delinquent Subcultures' in Delinquency, Crime, and Social Process. D. R. Cressey and D. A. Ward (eds.) (New York: Harper \& Row).

Cohen, A. K.: 1955, Delinquent Boys: The Culture of the Gang (Glencoe: Free Press). 
Colbert, A. E., M. K. Mount, J. K. Harter, L. A. Witt and M. R. Barrick: 2004, 'Interactive Effects of Personality and Perceptions of the Work Situation on Workplace Deviance'. Journal of Applied Psychology 89, 599-609.

Coleman, J.W.: 1987, 'Toward an Integrated Theory of White-Collar Crime'. American Journal of Sociology 93, 406-439.

Comer, M. J.: 1985, Corporate Fraud (London: McGraw-Hill).

Cressey, D. R.: 1950, 'The Criminal Violation of Financial Trust'. American Sociological Review 15, 738-743.

Cressey, D. R.: 1953, Other People's Money: A Study in the Social Psychology of Embezzlement (New York: Free Press).

Cressey, D. R.: 1965, ‘The Respectable Criminal: Why some of our Best Friends are Crooks', Criminologica 3, 13-16.

Daboub, A. J., A. M. A Rasheed, R. L. Priem and D. A .Gray: 1995, 'Top Management Team Characteristics and Corporate Illegal Activity’. Academy of Management Review 20, 138-170.

Darley, J.: 2003, ‘Social Comparison Motives in Ongoing Groups’ in Blackwell Handbook of Social Psychology: Group Processes. M. A. Hogg and S. Tindale (eds.) (Malden: Blackwell Publishing).

Darley, J. M.: 2001, ‘The Dynamics of Authority Influence in Organizations and the Unintended Action Consequences' in Social Influences on Ethical Behavior in Organizations. J. M. Darley, D. M. Messick and T.R. Tyler (eds.) (Mahwah: Lawrence Erlbaum Associates).

Davies, D.: 2000, Fraud Watch (London: ABG Professional Information).

Druskat, V. U. and J. V. Wheeler (2003): 2003, 'Managing from the Boundary: The Effective Leadership of Self-managing Work Teams’, Academy of Management Journal 46, 435-457.

Duffy, M. K., D. G. Ganster and M. Pagon: 2002, 'Social Undermining in the Workplace', Academy of Management Journal 45, 331-351.

Festinger, L.: 1954, ‘A Theory of Social Comparison Processes’, Human Relations 7, 117-140.

Fleming, P. and S. Zyglidopoulos: 2008, 'The Escalation of Deception in Organizations. Journal of Business Ethics (forthcoming).

Giacalone, R. A. and J. Greenberg: 1997, Antisocial Behavior in Organizations (Thousand Oaks: Sage Publications).

Giddens, A.: 1984, The Constitution of Society (Cambridge: Polity).

Goffman, E.: 1959, The Presentation of Self in Everyday Life (Garden City: Doubleday, Anchor Books).

Goffman, E.: 1974, Frame Analysis: An Essay on the Organization of Experience (Cambridge: Harvard University). 
Goldhagen, D. J.: 1996, Hitler's Willing Executioners: Ordinary Germans and the Holocaust (Toronto: Random House).

Gottfredson, M. R. and T. Hirschi: 1990, A General Theory of Crime (Stanford: Stanford University Press).

Greenberg, J. and R. Cropanzano: 2001, Advances in Organizational Justice (Stanford: Stanford University Press).

Hallier, J. and T. Forbes: 2004. 'In Search of Theory Development in Grounded Investigations: Doctors' Experiences of Managing as an Example of Fitted and Prospective Theorizing', Journal of Management Studies 41, 1379-1410.

Hambrick, D. C. and R. A. D’Aveni: 1988, ‘Large Corporate Failures as Downward Spirals’, Administrative Science Quarterly 33, 1-23.

Hegarty, W. H. and H. P. Sims: 1978, 'Some Determinants of Unethical Decision Behavior: An Experiment', Journal of Applied Psychology 63, 451-457.

Hobbs, D.: 1997, 'Criminal Collaboration: Youth Gangs, Subcultures, Professional Criminals, and Organized Crime’ in The Oxford handbook of criminology. M. Maguire, R. Morgan and R. Reiner (eds.) (Oxford: Oxford University Press).

Hoffman, W. M. and J. M. Moore: 1990, Business Ethics: Readings and Cases in Corporate Morality (New York: McGraw-Hill).

Hogg, M. A.: 2000, 'Social Identity and Social Comparison' in Handbook of Social Comparison: Theory and Research. J. Suls and L. Wheeler (eds.) (New York: Kluwer Academic).

Hogg, M. A.: 2003, 'Social Categorization, Depersonalization and Group Behavior' in Blackwell Handbook of Social Psychology: Group Processes. M. A. Hogg and S. Tindale (eds.) (Malden: Blackwell Publishing).

Hogg, M. A. and S. Tindale: 2003, Blackwell Handbook of Social Psychology: Group Processes (Malden: Blackwell Publishing).

Hollinger, R. C. and J. Clark: 1983, 'Deterrence in the Workplace: Perceived Certainty, Perceived Severity and Employee Theft', Social Forces 62, 398-418.

Jackall, R.: 1988, Moral Mazes: The World of Corporate Managers (New York: Oxford University Press).

Kaptein, M.: 2005, The Six Principles of Managing with Integrity: A Practical Guide. London: Articulate Press.

Kaptein, M. and S. Avelino: 2005, ‘Measuring Corporate Integrity: A Survey-based Approach’, Corporate Governance 5, 45-54.

Kerr, S.: 1975, 'On the Folly of Rewarding A, while Hoping for B', Academy of Management Journal 18, 769-783. 
King, R. R.: 2002, 'An Experimental Investigation of Self-serving Biases in an Auditing Trust Game: The Effect of Group Affiliation', The Accounting Review 77, 265-284.

Kohlberg, L.: 1981, Essays on Moral Development (San Francisco: Harper \& Row).

Leonard, D.: 1989, 'Market Behavior of Rational Addicts', Journal of Economic Psychology 10: 117-144.

Liedtka, J. M.: 1992, 'Exploring Ethical Issues Using Personal Interviews’, Business Ethics Quarterly 2, 161-181.

Lindsley, D. H., D. J. Brass and J. B. Thomas: 1995, 'Efficacy-Performance Spirals: A Multilevel Perspective', Academy of Management Review 20, 645-678.

Macy, M. W. and J. Skvoretz: 1998, The Evolution of Trust and Cooperation between Strangers: A Computational Model. American Sociological Review 63, 638-660.

Masuch, M.: 1985, 'Vicious Circles in Organizations', Administrative Science Quarterly 30, 14-33.

McCabe, K. A., M. L. Rigdon, and V. L. Smith: 2003, 'Positive Reciprocity and Intentions in Trust Games', Journal of Economic Behavior \& Organization 52, 267-275.

Mistangyi, V. F., G. R. Weaver and H. Elms: 2008, 'Ending Corruption: The Interplay between Institutional Logics, Resources, and Institutional Entrepreneurs. Academy of Management Review (forthcoming).

Moore, D. A., P. E. Tetlock, L. Tanlu and M. H. Bazerman: 2006, 'Conflicts of Interest and the Case of Auditor Independence: Moral Seduction and Strategic Issue Cycling', The Academy of Management Review 31, 10-29.

Paine, L. S.: 1994, 'Managing for Organizational Integrity’. Harvard Business Review 72, 106-117.

Paine, L. S.: 2003, Values Shift (New York: Prentice-Hall).

Pastin, M.: 1986, The Hard Problems of Management: Gaining the Ethics Edge (San Francisco: Jossey-Bass).

Perry, S. D., and Gonzenbach, W. J.: 2000, 'Inhibiting Speech through Exemplar Distribution: Can We Predict a Spiral of Silence?’, Journal of Broadcasting \& Electronic Media 44, 268-281.

Perry-Smith, J. E. and C. E. Shalley: 2003, 'The Social Side of Creativity: A Static and Dynamic Social Network Perspective', Academy of Management Review 28, 89-106.

Peterson, R. S.: 2001, 'Toward a More Deontological Approach to the Ethical Use of Social Influence' in Social Influences on Ethical Behavior in Organizations. J. M. Darley, D. M. Messick and T. R. Tyler (eds.) (Mahwah: Lawrence Erlbaum Associates).

Peterson, D. K.: 2002a, ‘Deviant Workplace Behavior and the Organization’s Ethical Climate’, Journal of Business and Psychology 17, 47-53.

Peterson, D. K.: 2002b, 'The Relationship between Unethical Behavior and the Dimensions of the Ethical Climate Questionnaire’, Journal of Business Ethics 41, 313-326.

Punch, M.: 1996, Dirty Business: Exploring Corporate Misconduct (London: SAGE Publications). 
Raelin, J. A.: 1994, 'Three Scales of Professional Deviance within Organizations’, Journal of Organizational Behavior 15, 483-501.

Reed, A. II and K. Aquino: 2003, 'Moral Identity and the Circle of Moral Regard towards Outgroups', Journal of Personality and Social Psychology 84, 1270-1286.

Reicher, S., S. A. Haslam and N. Hopkins: 2005, 'Social Identity and the Dynamics of Leadership: Leaders and Followers as Collaborative Agents in the Transformation of Social Reality', Leadership Quarterly 16, 547-568.

Ridgeway, C. L.: 1991, 'The Social Construction of Status Value: Gender and other Nominal Characteristics', Social Forces 70, 367-386.

Robinson, S. L. and R. J. Bennett: 1995, ‘A Typology of Deviant Workplace Behaviors: A Multidimensional Scaling Study', Academy of Management Journal 38, 555-572.

Robinson, S.L. and J. Greenberg: 1998, 'Employees Behaving Badly: Dimensions, Determinants and Dilemmas in the Study of Workplace Deviance', Trends in Organizational Behavior 5, 1-30.

Robinson, S. L. and A. M. O’Leary-Kelley: 1998, 'Monkey See, Monkey Do: The Influence of Work Groups on the Antisocial Behavior of Employees', Academy of Management Journal 41, 658-672.

Schweitzer, M. E., L. Ordóñez and B. Douma: 2004, 'Goal Setting as a Motivator of Unethical Behavior', Academy of Management Journal 47, 422-432.

Senge, P.: 1990, The Fifth Discipline: The Art and Practice of the Learning Organization (New York: Doubleday Currency).

Sherman, L. W.: 1980, 'Three Models of Organizational Corruption in Agencies of Social Control', Social Problems 27, 478-491.

Sherman, L. W.: 1985, 'Becoming Bent: Moral Careers of Corrupt Policeman’ in Moral Issues in Police Work. F. Elliston and A. Feldberg (eds.) (Pottzoa: Rowman \& Allanheld Publishers).

Sims, R. R. and J. Brinkmann: 2002, 'Leaders as Moral Role Models: The Case of John Gutfreund at Salomon Brothers', Journal of Business Ethics 35, 327-339.

Sims, R. R. and J. Brinkmann: 2003, ‘Enron Ethics (Or: Culture Matters More than Codes)’, Journal of Business Ethics 45, 243-256.

SmartPros: 2002, 'Anti-Fraud Body Calls for New Actions to Fight Corporate Fraud', July 25.

Staw, B. M.: 1981, 'The Escalation of Commitment to a Course of Action', Academy of Management Review 6, 577-587.

Staw, B. M., L. E. Sandelands and J. E. Dutton: 1981, 'Threat-Rigidity Effects in Organizational Behavior: A Multilevel Analysis’, Administrative Science Quarterly 26, 501-524.

Staw, B. M. and E. Szwajkowski: 1975, 'The Scarcity-Munificence Component of Organizational Environments and the Commission of Illegal Acts', Administrative Science Quarterly 20, 345-354. 
Stead, W.E., D. L. Worrell and G. J. Stead: 1990, 'An Integrative Model for Understanding and Managing Ethical Behavior in Business Organizations', Journal of Business Ethics 9, 233242.

Sterman, J. S.: 2000, Business Dynamics: System Thinking and Modeling for a Complex World (New York: McGraw-Hill).

Sundaramurthy, C. and M. Lewis: 2003, 'Control and Collaboration: Paradoxes of Governance', Academy of Management Review 28, 397-415.

Sutherland, E. H.: 1983, White Collar Crime: The Uncut Version (New Haven: Yale University Press).

Swartz, M. and S. Watkins: 2003, Power Failure: The Inside Story of the Collapse of Enron (New York: Doubleday).

Tajfel, H.: 1978, 'Social Categorization, Social Identity and Social Comparison' in Differentiation between Social Groups. H. Tajfel (eds.) (Oxford: Blackwell).

Tajfel, H.: 1982, Social Identity and Intergroup Relations (Cambridge: Cambridge University Press).

Tajfel, H. and J. C. Turner: 1979, 'An Integrative Theory of Intergroup Conflict' in The Social Psychology of Intergroup Relations. W. G. Austin and S. Worchel (eds.) (Monterey: Brooks/Cole).

The Financial Times: 2006, 'The Numbers Game: Meeting Quarterly Targets can be a Dangerous Addiction'. March $9^{\text {th }}$.

Tindale, R. S., H. M. Meisenhelder, A. A. Dykema-Engblade and M. A. Hogg: 2003, 'Shared Cognition in Small Groups' in Blackwell Handbook of Social Psychology: Group Processes. M. A. Hogg and S. Tindale (Malden: Blackwell Publishing).

Toffler, B. L. and J. Reingold: 2003, Final Accounting: Ambition, Greed and the Fall of Arthur Andersen (New York: Doubleday).

Treviño, L. K.: 1986, 'Ethical Decision Making in Organizations: A Person-Situation Interactionist Model', Academy of Management Review 11, 601-617.

Treviño, L. K., M. Brown and L. P. Hartman: 2003, ‘A Qualitative Investigation of Perceived Executive Ethical Leadership: Perceptions from Inside and Outside the Executive Suite', Human Relations 56, 5-37.

Treviño, L. K., K. D. Butterfield and D. L. McCabe: 1998, 'The Ethical Context in Organizations: Influences on Employee Attitudes and Behaviors', Business Ethics Quarterly 8, 447-476.

Treviño, L. K., L. P. Hartman and M. Brown: 2000, 'Moral Person and Moral Manager: How Executives Develop a Reputation for Ethical Leadership', California Management Review 42, 128142. 
Treviño, L. K. and G. R. Weaver: 2001, 'Organizational Justice and Ethics Program "Follow Through”: Influences on Employees’ Harmful and Helpful Behavior’, Business Ethics Quarterly 11, 651-671.

Treviño, L. K. and G. R. Weaver: 2003, Managing Ethics in Business Organizations: Social Scientific Perspectives (Stanford: Stanford University Press).

Treviño, L. K., G. R. Weaver, D. G. Gibson and B. L. Toffler: 1999, 'Managing Ethics and Legal Compliance: What Works and What Hurts', California Management Review 41, 131-151.

Treviño, L. K., G. R. Weaver, and S. Reynolds: 2006, 'Behavioral Ethics in Organizations: A Review’, Journal of Management 32: 951-990.

Treviño, L. K. and S. A. Youngblood: 1990, 'Bad Apples in Bad Barrels: A Causal Analysis of Ethical Decision-Making Behavior', Journal of Applied Psychology 75, 378-385.

Turner, J. C.: 1982, 'Towards a Cognitive Redefinition of the Social Group’ in Social Identity and Intergroup Relations. H. Tajfel (ed.) (Cambridge: Cambridge University Press).

Turner, J. C. and R. Brown: 1978, 'Social Status, Cognitive Alternatives, and Intergroup Relations' in Differentiation between Social Groups. H. Tajfel (ed.) (London: Academic Press).

Tyler, T. R. and S. L. Blader: 2000, Cooperation in Groups: Procedural Justice, Social Identity, and Behavioral Engagement (Philadelphia: Psychology Press, Taylor \& Francis Group).

Tyler, T. R. and S. L. Blader: 2005, 'Can Business Effectively Regulate Employee Conduct? The Antecedents of Rule Following in Work Settings', Academy of Management Journal 48, 1143-1158.

USA Today: 2005, 'CEO Trials Hold Startling Similarities’, February 21, 38.

Van Knippenberg, A.: 1978, 'Status Differences, Comparative Relevance and Intergroup Differentiation’ in Differentiation between Social Groups. H. Tajfel (ed.) (London: Academic Press).

Vardi, Y. and E. Weitz: 2004, Misbehavior in Organizations: Theory, Research, and Management (Mahwah: Lawrence Erlbaum Associates, Publishers).

Vaughan, D.: 1983, Controlling Unlawful Organizational Behavior: Social Structure and Corporate Misconduct (Chicago: The University of Chicago Press).

Weick, K. E.: 1979, The Social Psychology of Organizing (New York: Addison-Wesley).

Wells, J.: 2004, Corporate Fraud Handbook: Prevention and Detection (New York: John Wiley \& Sons).

Zey-Ferrell, M. and O. C. Ferrell (1982). 'Role-Set Configurations and Opportunities as Predictors of Unethical Behavior in Organizations', Human Relations 35, 587-604. 
Figure 1

Spirals within three organizational factors of corruption

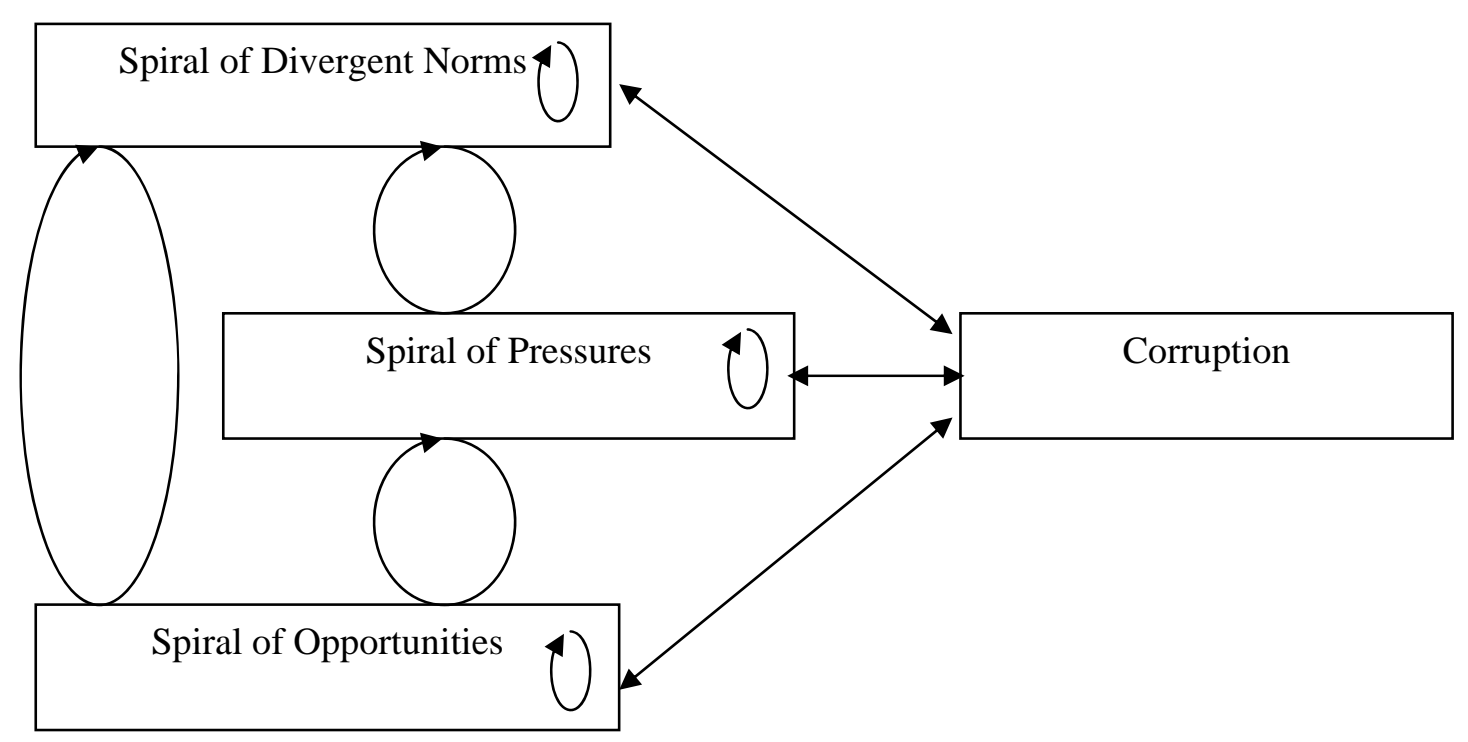


Table 1

Downward Corruption Spirals

\begin{tabular}{|c|c|c|}
\hline & Mechanism & Prediction \\
\hline Spiral of Divergent Norms & $\begin{array}{l}\text { Positive distinct- } \\
\text { iveness }\end{array}$ & $\begin{array}{l}\text { Corruption grows in organizations when norms } \\
\text { of groups change as a result of the competitive } \\
\text { nature of positive intergroup distinctiveness, as } \\
\text { this leads to a detachment and closing off of the } \\
\text { group from its environment. }\end{array}$ \\
\hline Spiral of Pressures & Identity threat & $\begin{array}{l}\text { Corruption grows in organizations as a result of } \\
\text { employees feeling pressured by and trying to } \\
\text { ward off identity threats though committing cor- } \\
\text { ruption. Employees get trapped into committing } \\
\text { more and more corruption, as identity threats } \\
\text { grow as a result of succumbing to identity threat } \\
\text { driven corruption }\end{array}$ \\
\hline Spiral of Opportunity & Prototypicality & $\begin{array}{l}\text { Corruption grows in organizations when the } \\
\text { room to commit corruption grows as a result of } \\
\text { diminishing sanctioning power of managers. } \\
\text { This results from a change in prototype after a } \\
\text { manager's initial failing to correct corrupt be- } \\
\text { havior. }\end{array}$ \\
\hline
\end{tabular}




\section{Notes}

${ }^{1}$ Downward spirals have been related to many organizational phenomena such as corporate failures (Hambrick and D’Aveni 1988), efficacy and performance (Lindsley, Brass and Thomas 1995), corporate governance (Sundaramurthy and Lewis 2003), public opinion (Perry and Gonzenbach 2000), enterprise resource planning systems (Akkermans and Helden 2002), and creativity (Perry-Smith and Shalley 2003). To our best knowledge, only two studies have explored downward spirals in the field of corruption. Both studies focus on one type of corruption, i.e. petty tyranny (Ashforth 1994) and workplace incivility (Andersson and Pearson 1999). Both studies also locate the downward spirals in interacting and escalating conduct, i.e. tit for tat, whereas we in this paper focus on interacting and escalating organizational factors behind conduct. 


\section{Publications in the ERIM Report Series Research* in Management}

\section{ERIM Research Program: "Organizing for Performance"}

2007

Leadership Behaviour and Upward Feedback: Findings From a Longitudinal Intervention

Dirk van Dierendonck, Clare Haynes, Carol Borrill and Chris Stride

ERS-2007-003-ORG

http://hdl.handle.net/1765/8579

The Clean Development Mechanism: Institutionalizing New Power Relations

Bettina B.F. Wittneben

ERS-2007-004-ORG

http://hdl.handle.net/1765/8582

How Today's Consumers Perceive Tomorrow's Smart Products

Serge A. Rijsdijk and Erik Jan Hultink

ERS-2007-005-ORG

http://hdl.handle.net/1765/8984

Product Intelligence: Its Conceptualization, Measurement and Impact on Consumer Satisfaction

Serge A. Rijsdijk, Erik Jan Hultink and Adamantios Diamantopoulos

ERS-2007-006-ORG

http://hdl.handle.net/1765/8580

Testing the Strength of the Iron Cage: A Meta-Analysis of Neo-Institutional Theory

Pursey P.M.A.R. Heugens and Michel Lander

ERS-2007-007-ORG

http://hdl.handle.net/1765/8581

Export Orientation among New Ventures and Economic Growth

S. Jolanda A. Hessels and André van Stel

ERS-2007-008-ORG

http://hdl.handle.net/1765/8583

Allocation and Productivity of Time in New Ventures of Female and Male Entrepreneurs

Ingrid Verheul, Martin Carree and Roy Thurik

ERS-2007-009-ORG

http://hdl.handle.net/1765/8989

Cooperating if one's Goals are Collective-Based: Social Identification Effects in Social Dilemmas as a Function of Goal-Transformation David De Cremer, Daan van Knippenberg, Eric van Dijk and Esther van Leeuwen

ERS-2007-010-ORG

http://hdl.handle.net/1765/9041

Unfit to Learn? How Long View Organizations Adapt to Environmental Jolts

Pursey P. M. A. R. Heugens and Stelios C. Zyglidopoulos

ERS-2007-014-ORG

http://hdl.handle.net/1765/9404

Going, Going, Gone. Innovation and Exit in Manufacturing Firms

Elena Cefis and Orietta Marsili

ERS-2007-015-ORG

http://hdl.handle.net/1765/9732 
High in the Hierarchy: How Vertical Location and Judgments of Leaders' Power are Interrelated

Steffen R. Giessner and Thomas W. Schubert

ERS-2007-021-ORG

http://hdl.handle.net/1765/9727

Contracts to Communities: a Processual Model of Organizational Virtue

Pursey P.M.A.R. Heugens, Muel Kaptein and J. van Oosterhout

ERS-2007-023-ORG

http://hdl.handle.net/1765/9728

Why Are Some Entrepreneurs More Innovative Than Others?

Philipp Koellinger

ERS-2007-024-ORG

http://hdl.handle.net/1765/9730

Stimulating Strategically Aligned Behaviour Among Employees

Cees B. M. van Riel, Guido Berens and Majorie Dijkstra

ERS-2007-029-ORG

http://hdl.handle.net/1765/10067

The Effectiveness of Business Codes: A Critical Examination of Existing Studies and the Development of an Integrated Research Model

Muel Kaptein and Mark Schwartz

ERS-2007-030-ORG

http://hdl.handle.net/1765/10150

Knowledge Spillovers and Entrepreneurs' Export Orientation

Dirk De Clercq, Jolanda Hessels and André van Stel

ERS-2007-038-ORG

http://hdl.handle.net/1765/10178

Silicon Valley in the Polder? Entrepreneurial Dynamics, Virtuous Clusters and Vicious Firms in the Netherlands and Flanders Willem Hulsink, Harry Bouwman and Tom Elfring

ERS-2007-048-ORG

http://hdl.handle.net/1765/10459

An Incomplete Contracting Model of Governance Structure Variety in Franchising

George Hendrikse and Tao Jiang

ERS-2007-049-ORG

http://hdl.handle.net/1765/10462

On the Evolution of Product Portfolio Coherence of Cooperatives versus Corporations: An Agent-Based Analysis of the Single Origin Constraint

George Hendrikse and Ruud Smit

ERS-2007-055-ORG

http://hdl.handle.net/1765/10505

Greenfield or Acquisition Entry: A Review of the Empirical Foreign Establishment Mode Literature

Arjen H.L. Slangen and Jean-François Hennart

ERS-2007-059-ORG

http://hdl.handle.net/1765/10539

Do Multinationals Really Prefer to Enter Culturally-Distant Countries Through Greenfields Rather than Through Acquisitions?

The Role of Parent Experience and Subsidiary Autonomy

Arjen H.L. Slangen and Jean-François Hennart

ERS-2007-060-ORG

http://hdl.handle.net/1765/10538 
The Financial Centres of Shanghai and Hong Kong: Competition or Complementarity?

Bas Karreman and Bert van der Knaap

ERS-2007-062-ORG

http://hdl.handle.net/1765/10516

Peer Influence in Network Markets: An Empirical Investigation

Jörn H. Block and Philipp Köllinger

ERS-2007-063-ORG

http://hdl.handle.net/1765/10540

Clustering in ICT: From Route 128 to Silicon Valley, from DEC to Google, from Hardware to Content

Wim Hulsink, Dick Manuel and Harry Bouwman

ERS-2007-064-ORG

http://hdl.handle.net/1765/10617

Leader Affective Displays and Attributions of Charisma: The Role of Arousal

Frederic Damen, Daan van Knippenberg and Barbara van Knippenberg

ERS-2007-067-ORG

http://hdl.handle.net/1765/10621

Unity through Diversity: Value-in-Diversity Beliefs, Work Group Diversity, and Group Identification

Daan van Knippenberg, S. Alexander Haslam and Michael J. Platow

ERS-2007-068-ORG

http://hdl.handle.net/1765/10620

Entrepreneurial Diversity and Economic Growth

Ingrid Verheul and André van Stel

ERS-2007-070-ORG

http://hdl.handle.net/1765/10619

Commitment or Control? Human Resource Management Practices in Female and Male-Led Businesses

Ingrid Verheul

ERS-2007-071-ORG

http://hdl.handle.net/1765/10618

Allocation of Decision Rights in Fruit and Vegetable Contracts in China

Yamei Hu and George Hendrikse

ERS-2007-077-ORG

http://hdl.handle.net/1765/10717

The Role of Transformational Leadership in Enhancing Team Reflexivity

Michaéla C. Schippers, Deanne N. Den Hartog, Paul L. Koopman and Daan van Knippenberg

ERS-2007-080-ORG

http://hdl.handle.net/1765/10720

Developing and Testing a Measure for the Ethical Culture of Organizations: The Corporate Ethical Virtues Model

Muel Kaptein

ERS-2007-084-ORG

http://hdl.handle.net/1765/10770

Postcards from the Edge: A Review of the Business and Environment Literature

Luca Berchicci and Andrew King

ERS-2007-085-ORG

http://hdl.handle.net/1765/10771

Spiraling Down into Corruption: A Dynamic Analysis of the Social Identity Processes that Cause Corruption in Organizations to Grow

Niki A. Den Nieuwenboer and Muel Kaptein

ERS-2007-086-ORG

http://hdl.handle.net/1765/10772 
* A complete overview of the ERIM Report Series Research in Management: https://ep.eur.nl/handle/1765/1

ERIM Research Programs:

LIS Business Processes, Logistics and Information Systems ORG Organizing for Performance

MKT Marketing

F\&A Finance and Accounting

STR Strategy and Entrepreneurship 